\title{
Söyleși
}

\section{Luciano IOGNA ile Forum Tiyatrosu Üzerine.}

\author{
Söyleşiyi yapan: Yrd. Doç. Dr. H. Ömer ADIGÜZEL \\ Çeviri: Tümay ÇOKLUK
}

\begin{abstract}
Kendinizi neden bir tiyatro iş̧̧isi olarak tanıtyyorsunuz? Ви Forum tiyatronun ideolojisinden mi ileri geliyor?

Bu politik bir görüş ve tamamen kişisel; başka insanlarla bir ilgisi yok. Yaptığım işin müzisyenlerin, oyuncuların, yönetmenlerin yaptıkları işlerden daha önemli olduğunu düşünmüyorum. Yazdığımda bir yazar, yönettiğimde bir yönetmen, oyunda rol aldığımda bir oyuncu oluyorum. Bunların hepsi benim için iş demek. 'Sanatçı' terimi bir çeşit üstünlük içerir. Ben buna inanmıyorum. Herkesle çalışabileceğimi düşünüyorum. Süreç içinde hepimizin söyleyecek sözleri var. Ben yaptığım şeyi bir iş olarak görüyorum.
\end{abstract}

\section{Türkiye'de Forum tiyatro hakkında hiçbir şey bilmeyen birine neler söyleyebilirsiniz?}

Yaptığımız şeyin kötü durum senaryoları ve gerçekliğin provası olan anti-modeller yaratmak olduğunu söyleyebilirim. İzleyici olarak izleyici - oyuncu olma fırsatı yakalayabilir ve oyunun akışını ve sonunu değiştirebilirsiniz.

Özellikle Augusto Boal'ın 'Ezilenlerin Tiyatrosu' üzerine kurduğunuz bir sanat yaklaşımınız var. Bu da anti-demokratik ülkeler için bir çözüm kaynă̆ı gibi. Bu konu hakkında neler düşünüyorsunuz?

Afrika'da buna 'Demokrasi Tiyatrosu' diyenler var. Çünkü herkesin söyleyecek bir şeyi var. Kuzey Amerika'da buna 'Kurtuluş Tiyatrosu' ya da 'Yaşam Tiyatrosu' diyoruz. Çünkü baskı kavramının Kuzey Amerika'da farklı bir anlamı var. 1998'de 1. Uluslararası İstanbul Çocuk Festivali'nde tekniğimizi uyguladığımızda basın yaptığımız şeyi 'Provokasyon Tiyatrosu' olarak nitelendirdi. Bazı şeyleri değiştirmek için izleyiciyi provoke ettiğimizi iddia ettiler.

Biz yaratıcı dramayı hem bir ders hem de bir yöntem olarak genellikle eğitimde kullanıyoruz. Türkiye'de özellikle son dönemlerde süreçsel drama ve Forum tiyatro bir teknik olarak çok daha fazla karşımıza çıkıyor. Bu, Türkiye'nin şu anki yapısıyla da ilgili çünkü sosyo-dramatik konular bizi çok 
ilgilendiriyor. Bu noktada Türkiye’nin rejimi ve ekonomik zayıflı̆̆ı da oldukça etkili. Dışarıdan bakıldı̆̆ında sizce Forum tiyatro Türkiye'nin bu sosyo-dramatik açı̆̆ını giderebilir mi?

Bence bu durum Türkiye'nin kendi içinde çözümlenmeli. Bu sorunlarla en etkili biçimde uğraşacak olanlar Türklerdir. Bu tür sorunlar yaşandığında Türkler neler yapılması gerektiğinin onlara dışarıdan söylenmesini bekliyor.

Augusto Boal bilinçli bir halk yetiştirmek için uğraşıyor. Eğitim sistemimizde de pek çok ülkede olduğu gibi sorunlar var. Bir tür 'katılımcı tiyatro' Türkiye benzeri ülkeler için yararlı olabilir mi? Elbette. Bence baskıcı rejimlerin olduğu ülkelerde bir tür yer altı hareketi bazı sorunları gidermek için yöntemler kullanabilir. Nijerya'da bunu yıllardır uygulayan biri var.

\section{Daha çok eğitim ve aydınlanma için bir araç gibi mi?}

Sanırım yaptığımız her şey politik. Yaptığımız her seçim politik bir karar.

Atölyelerde öznel hayatların paylaşıldığını görüyoruz. Konu drama olunca bir tür risk ve belirsizlik ortaya çıkıyor. Bunlar göz önüne alındı̆̆ında Forum tiyatro çalışacak bir kişinin nasıl bir donanıma sahip olması gerekir?

Bir katılımcı olarak bakacak olursak, neler olacağını bilemezsiniz çünkü baskı ile uğraşıyorsunuzdur. İlk günkü çalışmanın başında bahsettiğim üç kural vardı: kendinize zarar vermeyin, başkasına zarar vermeyin, mekana zarar vermeyin. Bu uyarılarıma rağmen insanlar kendilerine ve başkalarına zarar verebiliyor. İnsanlar öznel hayatlarındaki kötü anları anlatarak ve paylaşarak rahatlayabilir ancak bu belki atölyeye katılan diğer insanları olumsuz etkileyebilir. Lider olarak düşünürsek, bu olayların her birine hazırlıklı olmalı ve katılımcılara karşı da hassas olmalıyız. Atölyelerde çalışılan konular katılımcıların kendi konularıdır. Eşleri tarafından şiddet uygulanan kadınlar olabilir ve biz bu durumda onların anlatacağı bir şeyler olduğunu biliriz. İnsanlar kişisel hikayelerini anlatacaklardır. Bu durumda takınacağımız tavır bir terapistinkine yakın olmalıdır. Ancak kesin olarak neler olacağını asla bilemeyiz. İstanbul'da sahnelediğimiz bir oyunun önceki çeşitlemesinde konu aile ilişkileriydi. Sahnelerden biri erkek çocuğun babasına gay olduğunu söylemesiydi. Baba bunu kabul etmiyordu. İzleyicilerin arasından yaşlı bir adam sahneye girdi ve erkek çocuğun rolünü devraldı. Ben babayı oynuyordum ve çocuğumu evlatlıktan reddetme kararını verme aşamasındaydım. Erkek çocuğun yerine geçen o adam tişörtünü sıyırdı ve göğsündeki yaraları gösterip ağlamaya başladı. "Bana yaptığına bak. Neden bana vurdun?" dedi. Bu noktada o adama bir şeyler olduğunun farkındaydık. O adam oyun oynamıyordu. Bu hikayeden ayrı olarak kendi gerçekliğini sahneye taşıyordu. Ona anlatması için zaman tanıdık. Ben oyuncu kimliğimden, canlandırdığım karakterden sıyrılıp kendim oldum. Bir joker olarak bunun bazı şeylerin 
ötesinde olduğunu düşündüm. O durumun o adam için ne kadar önemli olduğunu gördüm. Ona bu yaşantısını bizimle paylaştığı için teşekkür ettik. Ancak biz oyunumuza devam etmeliydik. Neyse ki izleyicilerden biri o adama yardımcı olabilecek bir kurumun temsilcisiydi. Benim açımdan çok ilginç bir deneyimdi. Bu sadece Forum tiyatroda değil, her çeşit tiyatroda olabilecek bir şey. Vurucu bir sahne birçok kişiyi etkileyebilir. Kanada'da savaş karşıtı bir oyun sahnelerken izleyicilerden biri tiyatroyu terk etmeye çalıştı ve bayılıp düştü. Ambulans çağırdık ve o kişinin Vietnam Savaşı'na katılmak için Amerikan ordusuna yazılan bir Kanadalı olduğunu öğrendik. Oyundaki sahnelerden biri o kişinin öznel yaşamına çok benziyordu. Sunumda etkili olan her şeyin izleyici üzerinde de etkisi olabilir. Bazı şeyleri tetikleyebilir. Forum tiyatronun yaptığı şey izleyiciyi sahneye taşımak ve böylece olayları dolaylı yoldan anlatmak yerine onların birebir yaşanmasını sağlamaktır.

Forum tiyatroda sadece baskı, ezenler ve ezilenler arasındaki ilişki mi söz konusu? Forum tiyatroya eğitimi dahil edebilir miyiz?

Ben bir öğretmen değilim. Bazı konularda tam bilgiye sahip değilim. Bir kadın değilim; şiddete maruz kalan kadınlarla çalıştığımda izleyicilerin kendi adlarına bir şeyler öğrenmelerini beklerim. Genç izleyicilere yönelik tiyatro yapıyorsam joker olarak rolüm değişir. Manipülasyonları öğretmeye çalışırım ancak bunu sorular sorarak yaparım. Baskı konusunu işlerken insanların biraz da eğlenebilecek olmalarına güvenirim. İnsanların kendi yaşantılarını ve cesaretlerini o konularla bağdaştırabilmelerini isterim. Eğer vatansever bir tavırla insanlara yaklaşırsam daha fazla yabancılaşırlar.

'Ben Bir Şey Yapmadım Öğretmenim' adlı oyunumuzda Forum tiyatro kullanmayı denedik. Herkes sırayla öğretmen karakterini canlandırdı. Aslında o oyunda baskı daha çok anneden geliyordu.

Evet.

Bu semineri nasıl değerlendiriyorsunuz? Katılımcıların çoğu tiyatrocu ve eğitimciydi. Bir lider olarak tasarladıklarınızı uygulayabildiniz mi?

Hayır. Katılımcı sayısı konusunda sorunlarım oldu. Bir başka sorun ise zaman konusundaydı. Söylediklerimin Türkçe'ye çevrilme zorunluluğu sıkıntı yarattı. Eğer daha çok zaman ve daha az katılımcı olsaydı daha verimli bir süreç olabilirdi. Ancak bu Türk kültürüne uyan bir şey ve katılımcıların alışık olduğu bir durum. Bu ayrıca öğrenme sürecinin bir parçası. Katılımcıların çoğunun tiyatrocu ve eğitimci olması sorun olmadı. Ben idari personelle, doktorlarla, hemşirelerle, tıp öğrencileriyle, itfaiyecilerle ve çok farklı gruplarla çalıştım. Önemli olan şey onların bir arzusu olmasıydı. Son altı yılda beş kez Türkiye'ye gelmemin sebebi benim de büyük bir arzumun olmasıdır. Bunu da çok heyecan verici buluyorum. 


\section{Ĕ̆gr Birleşmiş Milletler dünya liderleriyle Forum tiyatro yapsaydı neler olurdu?}

Nerede sahneleyeceklerini bilemezdim. Augusto Boal'ın 'Resmi Tiyatro' olarak nitelendirdiği bir tiyatro var. Biz bunu Toronto'da belediye idari çalışanlarına uyguladık. Ancak büyük bir dirençle karşılaştık. Çünkü kullandığımız teknik onları kültürümüze adapte etmek amaçlıydı. Önemli olan, tekniğin böyle bir duruma uyarlanabilmesiydi. 